\title{
Arsenic trioxide induces the apoptosis and decreases NF-кB expression in lymphoma cell lines
}

\author{
$\mathrm{LU} \mathrm{ZHONG}^{1}$, FEI XU ${ }^{2}$ and FANGYUAN CHEN ${ }^{1}$ \\ ${ }^{1}$ Department of Hematology, Renji Hospital Affiliated to Shanghai Jiaotong University, Shanghai 200001; \\ ${ }^{2}$ Department of Ultrasound, The Affiliated Shuhuang Hospital of University of Shanghai Chinese Medicine, \\ Shanghai 201111, P.R. China
}

Received January 13, 2017; Accepted April 16, 2018

DOI: $10.3892 / \mathrm{ol} .2018 .9424$

\begin{abstract}
Lymphoma is a type of cancer that develops from certain immune system cells. Arsenic trioxide (ATO) has attracted wide attention owing to its antitumor activities. However, the role of ATO in tumorigenesis and progression remains to be investigated. In the present study, the antitumor function of ATO was investigated in in lymphoma Raji and Jurkat cell lines and the effect of ATO on nuclear factor $(\mathrm{NF})-\kappa \mathrm{B}$ expression levels. A Cell Counting kit-8 assay was used to assess cellular proliferation and the degree of cell apoptosis was measured by flow cytometric analysis; these assays demonstrated that ATO inhibited proliferation and promoted the apoptosis of Raji and Jurkat cells in a dose- and time-dependent manner. Western blot analysis revealed that ATO treatment affected the expression of apoptosis-associated proteins by downregulating the anti-apoptotic protein B-cell lymphoma-2 (Bcl-2) and upregulating the pro-apoptotic protein $\mathrm{Bcl}-2$-associatedX and the degree of caspase-3 cleavage. In addition, reverse transcription-quantitative polymerase chain reaction and western blot analysis showed that the mRNA and protein expression levels of NF- $\kappa \mathrm{B}$ were downregulated significantly following treatment with $2 \mu \mathrm{M}$ ATO for 24, 48 and $72 \mathrm{~h}$ in the two cell lines. Additionally, immunofluorescence staining indicated that NF- $\kappa \mathrm{B}$ expression diminished following ATO treatment in a time-dependent manner. These data indicated that ATO inhibited the proliferation of lymphoma cells by inducing cell apoptosis, which may be associated with the inhibition of the NF- $\kappa$ B signaling pathway. The findings of the present study may lay the foundation for developing a personalized medicine strategy
\end{abstract}

Correspondence to: Dr Fangyuan Chen, Department of Hematology, Renji Hospital Affiliated to Shanghai Jiaotong University, 145 Shandong Middle Road, Shanghai 200001, P.R. China

E-mail: chfyuanqq@163.com

Key words: arsenic trioxide, apoptosis, nuclear factor- $\kappa \mathrm{B}$, lymphoma, reverse transcription polymerase chain reaction, western blotting using ATO via targeting of the NF- $\mathrm{NB}$ signaling pathway in lymphoma.

\section{Introduction}

Lymphoma is the name given to a group of blood cell tumors that begin in lymphocytes (a type of white blood cell), the incidence rate of which has increased slightly among men in recent years (1-3). In recent years, mortality rates for lymphoma have been decreasing; however, certain types of lymphoma are more aggressive and these patients have a lower survival rate $(2,3)$. Therefore, investigating effective therapeutic approaches is necessary to prolong survival of patients with lymphoma.

Tumors are caused by abnormal cell proliferation, differentiation and apoptosis, which are due to the activation of certain proto-oncogenes, inactivation of tumor suppressors and alterations to apoptosis-associated genes (4,5). Apoptosis, a programmed cell death, exerts a notable role by allowing cells to respond appropriately to environmental stimuli (6). Tumorigenesis and progression of a number of types of human cancer are associated with the dysregulation of the apoptotic process $(7,8)$.

A number of chemotherapeutic agents have been demonstrated to serve antitumor roles by inducing cell apoptosis, resulting in the death of cancer cells (9-11). The application of arsenic trioxide (ATO), an inorganic compound with the formula $\mathrm{As}_{2} \mathrm{O}_{3}$, is controversial owing to the high toxicity of arsenic compounds (12). Despite the toxicity of arsenic, arsenic trioxide has been used in a number of traditional Chinese medicines, and has been used to treat cancer (13). Previous studies have identified that ATO induces apoptosis in acute promyelocytic leukemia (APL) cells $(14,15)$, glioblastoma cells $(16)$ and gastric cancer cells (17), and inhibits cell growth in breast cancer (18). The use of ATO is also being evaluated for the treatment of certain malignancies, including lung cancer (19), hepatocellular cancer (20) and basal cell cancer (21). Although ATO exhibits a significant antitumor function in multiple cancer types, its exact effect on lymphoma and the underlying mechanism of action remain under investigation.

Nuclear factor $-\kappa \mathrm{B}(\mathrm{NF}-\kappa \mathrm{B})$ is a protein complex that controls the transcription of DNA, cytokine production and cell survival (22). The dysfunctional regulation of $\mathrm{NF}-\kappa \mathrm{B}$ has been associated with cancer, inflammatory and 
autoimmune diseases, septic shock, viral infection and improper immune development (23-26). NF- $\kappa \mathrm{B}$ has been recognized as one of the dominant oncogenes associated with lymphoma (27). NF- $\mathrm{B}$ has emerged as a central player in the development and maintenance of lymphoma (28). It has been revealed that the constitutive activation of the canonical and non-canonical NF- $\mathrm{B}$ signaling pathways has been observed in Hodgkin and Reed/Sternberg cells in classical Hodgkin lymphoma (27). It has also been reported that the inhibition of $\mathrm{NF}-\kappa \mathrm{B}$ activity is involved in the apoptosis of lymphoma cells (27).

The present study investigated the effect of ATO on the proliferation and apoptosis in human lymphoma cells was investigated and the underlying molecular mechanism, with particular focus on intracellular expression and localization of NF- $\mathrm{BB}$, and levels of apoptosis-associated proteins B-cell lymphoma-2 (Bcl-2), Bcl-2-associated $\mathrm{X}$ protein (Bax) and caspase-3.

\section{Materials and methods}

Cell cultures and treatments. The human B lymphoma Raji cell line and human T lymphoma Jurkat cell line were purchased from Shanghai Institute of Pharmaceutical Industry (Shanghai, China). Cells were cultured in RPMI-1640 medium (Sigma-Aldrich; Merck KGaA, Darmstadt, Germany) supplemented with $10 \%$ fetal bovine serum (FBS; Hangzhou Sijiqing Biological Engineering Materials Co., Ltd., Hangzhou, China) and $100 \mu \mathrm{g} / \mathrm{ml}$ penicillin and streptomycin (Sigma-Aldrich, St. Merck, KGaA, Darmstadt, Germany). Cell lines were cultured at $37^{\circ} \mathrm{C}$ in a $5 \% \mathrm{CO}_{2}$ incubator.

Cell viability assay. Cell viability was evaluated using Cell Counting kit-8 (CCK-8; Beyotime Institute of Biotechnology, Haimen, China). A total of $2 \times 10^{5}$ cells per well were seeded in a 96-well plate and cultured at $37^{\circ} \mathrm{C}$ with $5 \% \mathrm{CO}_{2}$ to $80 \%$ confluence, and then were treated with ATO (Sigma-Aldrich; Merck KGaA) at $0.5,1,2,4,10$ and $30 \mu \mathrm{M}$ for 24, 48 and $72 \mathrm{~h}$. Next, cells were incubated with CCK-8 reagent according to the manufacturer's protocol and the number of viable cells was measured by recording the optical density by using a Rainbow microplate reader (Tecan Group, Ltd., Mannedorf, Switzerland) at a wavelength of $450 \mathrm{~nm}$, as described previously (29). The cell growth inhibition rate was calculated according to the formula: Growth inhibition rate $(\%)=[1-\mathrm{A}$ (experimental group)/A (control group)] $\mathrm{x} 100$, where $\mathrm{A}$ is the absorbance value. The half-maximal inhibitory concentration $\left(\mathrm{IC}_{50}\right)$ value was adopted as the concentration of drug intervention in future experiments in vitro.

Cell morphology observation. A total of $1 \times 10^{5}$ Raji cells or Jurkat cells per well were seeded in a 24 -well plate and cultured at $37^{\circ} \mathrm{C}$ with $5 \% \mathrm{CO}_{2}$ to reach $\sim 80 \%$ confluence, and then were treated with or without 2 or $3.5 \mu \mathrm{M}$ ATO for 0,24 , 48 , and $72 \mathrm{~h}$. Cells were harvested and centrifuged in $1,000 \mathrm{x} \mathrm{g}$ for $15 \mathrm{~min}$ at $4^{\circ} \mathrm{C}$. Cells were washed with PBS three times, and then were placed onto a glass slide and the slides were stained with Wright's stain (Magnil Dye Chem, Maharashtra, India) according to manufacturer's protocol. The glass slides were rinsed briefly in running deionized water ( $\mathrm{pH}$ 7.2) and dried in air thoroughly before capturing images by a microscope (Olympus BX51, Olympus Corporation, Tokyo, Japan) at $\mathrm{x} 1,000$ magnification.

Detection of early cell apoptosis and necrosis. Raji cells or Jurkat cells were grown to $80 \%$ confluence and treated with 2 or $3.5 \mu \mathrm{M}$ ATO, respectively, for $0,24,48$ and $72 \mathrm{~h}$ at $37^{\circ} \mathrm{C}$. ATO for different time periods. Apoptosis was quantified by an Annexin V-fluorescein isothiocyanate (FITC)/propidium iodide (PI) assay (BD Biosciences, Franklin Lakes, NJ, USA) following the manufacturer's protocol. The Annexin V-FITC/PI assay detects the quantity of phosphatidylserine on the outer surface of the plasma membrane (a biochemical alteration unique to membranes of apoptotic cells) and the quantity of PI, a dye that readily enters dead cells or cells undergoing late-stage apoptosis and binds to DNA but does not bind to the plasma membrane of viable cells. Cytoclasis rate (Necrosis rate) was detected by PI single staining. Fluorescence was detected using a FACSCalibur flow cytometer (BD Biosciences, Franklin Lakes, NJ, USA), and data were analyzed using CellQuest version 3.2 software (BD Biosciences). Cells with phosphatidylserine on their surface were considered to be apoptotic.

Western blot analysis. Cells were collected and lysed in lysis buffer (50 mM Tris- $\mathrm{HCl}$ (pH 7.4), $1 \mathrm{mM}$ EDTA, $1 \%$ NP40, $150 \mathrm{mM} \mathrm{NaCl}, 10 \mathrm{mM} \mathrm{NaF}$ and $1 \mathrm{mM} \mathrm{Na}_{3} \mathrm{VO}_{4}$ ) containing a protease inhibitor cocktail (Roche Applied Science, Penzberg, Germany). Following centrifugation at $12,000 \mathrm{x} \mathrm{g}$ for $10 \mathrm{~min}$ at $4^{\circ} \mathrm{C}$, the supernatant was collected and quantified using a Bicinchoninic acid (BCA) quantification kit (Beyotime Institute of Biotechnology, Haimen, China). Protein samples $(50 \mu \mathrm{g})$ were separated by $10 \%$ SDS-PAGE (Bio-Rad Laboratories, Inc., Hercules, CA, USA) and transferred to polyvinylidene fluoride membranes (EMD Millipore, Billerica, MA, USA). The membranes were blocked with $5 \%$ non-fat dried milk in Tris-buffered saline containing $0.05 \%$ Tween 20 for $1 \mathrm{~h}$ at room temperature, and incubated with the following specific primary antibodies overnight at $4^{\circ} \mathrm{C}$ : Rabbit polyclonal $\mathrm{IgG}$ to $\mathrm{NF}-\kappa \mathrm{B}$ (1:1,000; cat no. ab16502; Abcam, Cambridge, UK); mouse monoclonal IgG to Bcl-2 (1:500; vat no. sc7382; Santa Cruz Biotechnology, Inc., Dallas, TX, USA); rabbit polyclonal IgG to Bax (1:500; cat no. sc493; Santa Cruz Biotechnology, Inc.); mouse monoclonal IgG to $\beta$-actin $(1: 1,000$; cat no. sc47778; Santa Cruz Biotechnology, Inc.); rabbit polyclonal IgG to cleaved-caspase-3 (1:1,000; cat no. 9661S; Cell Signaling Technology,Inc., Danvers, MA, USA), followed by horseradish peroxidase-conjugated secondary antibodies goat anti-mouse (1:2,000; cat no. sc-2005; Santa Cruz Biotechnology, Inc.) and goat anti-rabbit IgG (1:2,000; cat no. sc-2004; Santa Cruz Biotechnology, Inc.) for $2 \mathrm{~h}$ at room temperature. An Enhanced Chemiluminescence detection reagent (GE Healthcare, Chicago, IL, USA) was used for development. Additionally, IRDye ${ }^{\circledR} 800 \mathrm{CW}$-labeled secondary antibodies goat anti-mouse $(1: 10,000$; cat no. ab216772; Abcam, Cambridge, MA) and anti-rabbit immunoglobulin G (1:10,000; cat no. ab216773; Abcam) were used to incubation for $1 \mathrm{~h}$ at room temperature. Membranes were visualized and imaged using an Odyssey infrared imaging system (LI-COR, 
Lincoln, NE, USA). The gray value of the targeted bands was quantified with QuantityOne software version 4.6.2 (Bio-Rad Laboratories, Inc., Hercules, CA, USA) following incubation, with $\beta$-actin used as the internal reference.

Immunofluorescence and confocal microscopy. The procedure was performed as previously described (30). Raji cells or Jurkat cells were fixed with $3 \%$ formaldehyde in PBS for $20 \mathrm{~min}$ at room temperature. After three washes with PBS containing $50 \mathrm{mM} \mathrm{NH}_{4} \mathrm{Cl}$, the cells were soaked in a blocking solution (PBS containing 5\% fetal calf serum, FCS; Hangzhou Sijiqing Biological Engineering Materials Co., Ltd., Hangzhou, China) for $15 \mathrm{~min}$ at room temperature and then permeabilized with $0.1 \%$ Triton $\mathrm{X}-100$ in PBS for $5 \mathrm{~min}$. Cells were incubated with anti-NF- $\kappa \mathrm{B}$ antibody (1:1,000; cat no. 8242; Cell Signaling Technology, Inc., Danvers, MA, USA) overnight at $4^{\circ} \mathrm{C}$, and stained with a rhodamine-fluorescence labeled goat anti-rabbit secondary antibody (1:1,000; cat no. 15076; Active motif, Inc., Carlsbad, CA, USA) in 1\% blocking solution (PBS containing $1 \% \mathrm{FCS}$ ) and incubated for $1 \mathrm{~h}$ at room temperature. Confocal imaging was performed with an LSM META510 confocal scanning laser microscope (Carl Zeiss AG, Oberkochen, Germany) at x1,000 magnification. The images were subsequently analyzed using the freely available image processing software ImageJ Version 1.46 (National Institute of Health, Bethesda, Maryland, USA). The observations were made in triplicates, and representative images are presented here.

Reverse transcription-quantitative polymerase chain reaction (RT-qPCR). Total RNA was extracted from Raji cells or Jurkat cells with TRIzol reagent (cat no. 15596-026; Invitrogen; Thermo Fisher Scientific, Inc., Waltham, MA, USA) according to the manufacturer's protocol. Total RNA isolated by TRIzol reagent was free of protein and DNA contamination. For RT-qPCR, the isolated RNA was treated with amplification grade DNase I (cat no. 18068-015; Invitrogen, Thermo Fisher Scientific, Inc.). cDNA was obtained by RT using the RevertAid ${ }^{\mathrm{TM}}$ First Strand cDNA synthesis kit (Fermentas; Thermo Fisher Scientific, Inc.). The relative mRNA expression levels of target genes were detected with a specific TaqMan ${ }^{\circledR}$ Gene Expression assay (Applied Biosystems; Thermo Fisher Scientific, Inc.) with fluorogenic FAM-labeled probes. Primers for $\mathrm{NF}-\kappa \mathrm{B}$ and internal control RNA polymerase II (RPII) were designed $(31,32)$, and were synthesized by Shanghai Institute of Pharmaceutical Industry (Shanghai, China). The primers sequences were as follows: $N F-\kappa B$, forward 3 '-GGA TTTCGTTTCCGTTATG-5' and reverse 3'-GGTTTGCGA AGCCGACCA-5'; RPII (internal control), forward 3'-GCA CCACGTCCAATGACAT-5' and reverse 3'-GTGCGGCTG CTTCCATAA-5'.

The two genes were amplified by a first step of $120 \mathrm{sec}$ at $95^{\circ} \mathrm{C}$, followed by 45 cycles of $30 \mathrm{sec}$ at $95^{\circ} \mathrm{C}, 30 \mathrm{sec}$ at $60^{\circ} \mathrm{C}$ and $30 \mathrm{sec}$ at $72^{\circ} \mathrm{C}$. The real-time fluorescence detection was performed using the ABI PRISM 7700 Sequence detector (PerkinElmer, Inc., Waltham, MA, USA). NF- $\mathrm{B}$ expression was normalized to the expression of the reference RPII and was calculated using the $2^{\Delta \Delta \mathrm{Cq}}$ method (33).
Statistical analysis. At least three replicates were performed within the same experiment. The statistical package SPSS version 16.0 (SPSS, Inc., Chicago, IL, USA) was used to assay the experimental data. Differences were analyzed using one-way analysis of variance, and $\mathrm{P}<0.05$ was considered to indicate a statistically significant difference.

\section{Results}

ATO treatment inhibits the growth of lymphoma Raji and Jurkat cell lines. Human lymphoma Raji and Jurkat cell lines were treated with ATO at $0.5,1,2,4,10$ and $30 \mu \mathrm{M}$ for 24,48 and $72 \mathrm{~h}$. Cell viability was evaluated using a CCK-8 assay and the cell growth inhibition rate was calculated. As depicted in Fig. 1A and B, ATO treatment inhibited the proliferation of Raji and Jurkat cells in a dose- and time-dependent manner. ATO treatment at $0.5 \mu \mathrm{M}$ for 24 and $48 \mathrm{~h}$ did not result in significant proliferation inhibition in Raji cells, whereas ATO treatment at other concentrations for 24 and $48 \mathrm{~h}$ and ATO treatment at all concentrations for $72 \mathrm{~h}$ exhibited significant proliferation inhibition activity (Fig. 1A). Additionally, $0.5 \mu \mathrm{M}$ ATO treatment for $24 \mathrm{~h}$ did not show a significant proliferation inhibition in Jurkat cells, whereas ATO treatment at the other concentrations for $24 \mathrm{~h}$ and ATO treatment at all concentrations for 48 and $72 \mathrm{~h}$ showed significant proliferation inhibition activity (Fig. 1B). The $\mathrm{IC}_{50}$ values of the two cell lines were then calculated, which were $2.06 \mu \mathrm{M}$ for Raji cells and $3.75 \mu \mathrm{M}$ for Jurkat cells at $24 \mathrm{~h}$.

ATO treatment induces morphological changes in Raji and Jurkat cells. The survival capabilities of Raji cells treated with $2 \mu \mathrm{M}$ ATO and Jurkat cells treated with $3.5 \mu \mathrm{M}$ ATO for 0,24 , 48 and $72 \mathrm{~h}$, were compared by observing their morphology using Wright's staining. The two cell lines exhibited significant apoptotic features following ATO treatment for 24 and $48 \mathrm{~h}$, with enlarged cells, enlarged vacuole, reduced nucleoplasm, rough nuclear chromatin, reduced nucleolus and pyknosis, and nuclear apoptotic bodies, compared with untreated control cells (Fig. 2A and B). The two cell lines treated with ATO for $72 \mathrm{~h}$ exhibited significant morphological alterations with cellular debris for dead cells (Fig. 2A and B).

ATO treatment induces apoptosis of lymphoma Raji and Jurkat cell lines. Raji and Jurkat cell lines were treated with $2 \mu \mathrm{M}$ or $3.5 \mu \mathrm{M}$ ATO for 24,48 and $72 \mathrm{~h}$. Cell apoptosis was evaluated by flow cytometric analysis. The results revealed that the apoptosis of Raji and Jurkat cells was significantly increased by ATO treatment for 24 and $48 \mathrm{~h}$ compared with ATO-untreated control cells. However, ATO-induced cell apoptosis at $72 \mathrm{~h}$ was lower than that at $48 \mathrm{~h}$ (Fig. 3A). Additionally, the cytoclasis rate was increased by ATO treatment for 48 and $72 \mathrm{~h}$ compared with ATO-untreated control cells (Fig. 3A). The expression levels of apoptosis-associated proteins were detected. Western blot analysis demonstrated that ATO treatment for $48 \mathrm{~h}$ reduced the expression of the anti-apoptotic protein Bcl-2 and elevated that of the pro-apoptotic protein Bax and the levels of cleaved caspase-3 (Fig. 3B). These data indicated that ATO inhibited the growth of lymphoma Raji and Jurkat cells, possibly by inducing cell apoptosis, with the abnormal expression of apoptosis-associated proteins. 

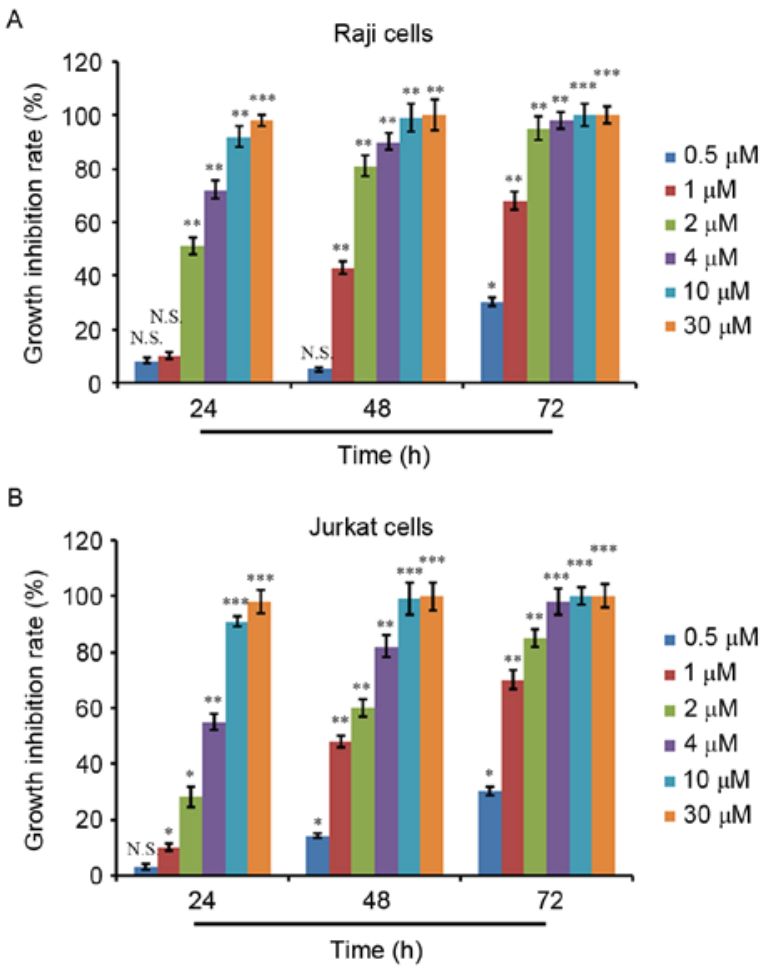

Figure 1. Inhibition of ATO treatment on growth of lymphoma Raji and Jurkat cells. (A) Raji and (B) Jurkat cells were treated with 0.5, 1, 2, 4, 10 and $30 \mu \mathrm{M}$ ATO for 24,48 and $72 \mathrm{~h}$. Cell growth was evaluated using a Cell Counting kit-8 and the cell growth inhibition rate was calculated. ATO, arsenic trioxide. N.S, not significant. ${ }^{*} \mathrm{P}<0.05,{ }^{* *} \mathrm{P}<0.01$ and ${ }^{* * *} \mathrm{P}<0.001$ vs. $0.5 \mu \mathrm{M}$ ATO-treated cells.

ATO inhibits protein and $m R N A$ expression levels of $N F-\kappa B$. To investigate the underlying mechanism behind the ATO-dependent induction of apoptosis in Raji and Jurkat cells, the two cells were treated with 2 or $3.5 \mu \mathrm{M}$ ATO, respectively, for $0,12,24,48$ and $72 \mathrm{~h}$. Next, NF- $\mathrm{kB}$ protein and mRNA expression levels were evaluated by western blot analysis and RT-qPCR. The results revealed that NF-kB protein expression in Raji and Jurkat cells was decreased by ATO treatment in a time-dependent manner (Fig. 4A), and quantification analysis supported these results (Fig. 4B). NF- $\kappa$ B mRNA expression levels were also significantly reduced by ATO treatment for 24 , 48 and $72 \mathrm{~h}$ in the two cell lines compared with ATO-untreated control cells. However, there was no significant difference in the mRNA expression levels of NF- $\kappa B$ at 24,48 and $72 \mathrm{~h}$ (Fig. 4C). These results indicated that NF- $\mathrm{kB}$ protein and mRNA expression levels decreased during ATO-induced cell apoptosis in lymphoma Raji and Jurkat cells.

ATO treatment affects the sub-cellular localization of $N F-\kappa B$. To investigate the status of NF- $\mathrm{KB}$ during ATO-induced cell apoptosis in Raji and Jurkat cells, the two cell lines were treated with ATO (at the aforementioned concentrations) for $0,12,24$, 48 and $72 \mathrm{~h}$, and then the sub-cellular localization of NF- $\mathrm{\kappa B}$ was detected by immunofluorescence analysis. The results revealed that fluorescently labeled $\mathrm{NF}-\kappa \mathrm{B}$ was expressed in the nucleus and cytoplasm of the two cell lines prior to ATO treatment, whereas NF- $\kappa \mathrm{B}$ expression diminished gradually following ATO treatment for 12 and $24 \mathrm{~h}$, and was only observed in the cytoplasm after 48 and 72 h (Fig. 5). Nuclei
A

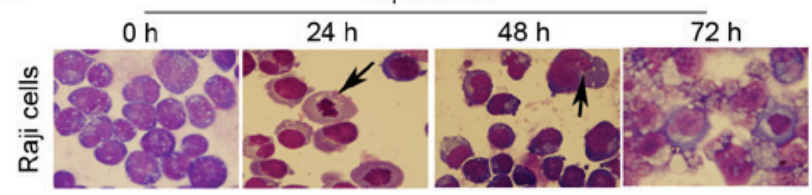

B

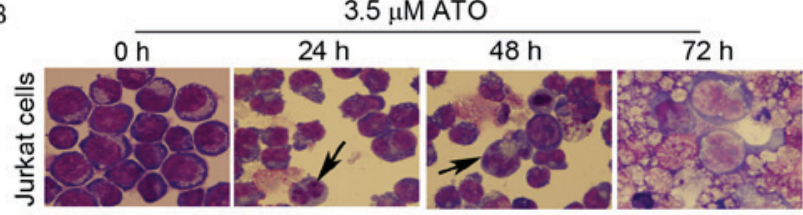

Figure 2. Morphological alterations of Raji and Jurkat cells prior to and following ATO treatment. (A) Raji and (B) Jurkat cells were treated with 2 and $3.5 \mu \mathrm{M}$ ATO, respectively, for $0,24,48$ and $72 \mathrm{~h}$. Cell morphologies were compared using Wright's staining (magnification, $\mathrm{x} 1,000$ ). ATO, arsenic trioxide. The arrows represent apoptotic cells.

were stained using DAPI (data not shown). Fluorescence of NF- $\kappa \mathrm{B}$ protein expression was clearly observed all over the visible cells under weak light prior to ATO treatment, while fluorescence was only observed around the cell membranes following ATO treatment for 48 and $72 \mathrm{~h}$. These data indicated that NF- $\mathrm{kB}$ may be associated with ATO-induced cell apoptosis in lymphoma Raji and Jurkat cells, with alterations of NF- $\mathrm{KB}$ protein expression levels and sub-cellular localization from the nucleus to the cytoplasm.

\section{Discussion}

Studies concerning acute leukemia have verified that ATO serves a critical role in the inhibition of leukemia cell proliferation, promotion of cell differentiation and stimulation of cell apoptosis $(14,15)$. ATO may also inhibit the proliferation of various types of lymphoma cells (34-36), including Burkitt lymphoma, by reducing mitochondrial membrane potential $(37,38)$, consuming ATP and prolonging the cell cycle, downregulating the proto-oncogene $\mathrm{Bcl}-2$, and upregulating tumor protein p53 (39). Previous studies have also revealed that ATO increases the proportion of cells in the $\mathrm{G}_{2} / \mathrm{M}$ phase of the cell cycle in lymphoma cells, which is sufficient to induce cell apoptosis (40).

The present study revealed that ATO might inhibit the proliferation of B lymphoma Raji cells and T lymphoma Jurkat cells, which was time- and drug-concentration-dependent. ATO at a concentration of $0.5 \mu \mathrm{M}$ (dosage for acute promyelocytic leukemia (APL) apoptosis (41) showed little inhibition on growth in the two cell lines, indicating that the dosage for clinical ATO treatment of lymphoma may possibly exceed the dosage for APL treatment. Cell morphology observation and flow cytometric analysis indicated that the two cell lines exhibited features of apoptosis following ATO treatment for 24 and $48 \mathrm{~h}$, whereas the cytosomes of the two cell lines underwent clear necrosis that was shown by cytoclasis rate following ATO treatment for $72 \mathrm{~h}$. These data demonstrated that ATO might inhibit the proliferation of lymphoma Raji and Jurkat cells by inducing apoptosis. Additionally, it was found that the dosage of ATO that was able to inhibit the growth of T lymphoma Jurkat cells by inducing cell apoptosis was higher than that required for growth inhibition in B lymphoma Raji cells. 
A

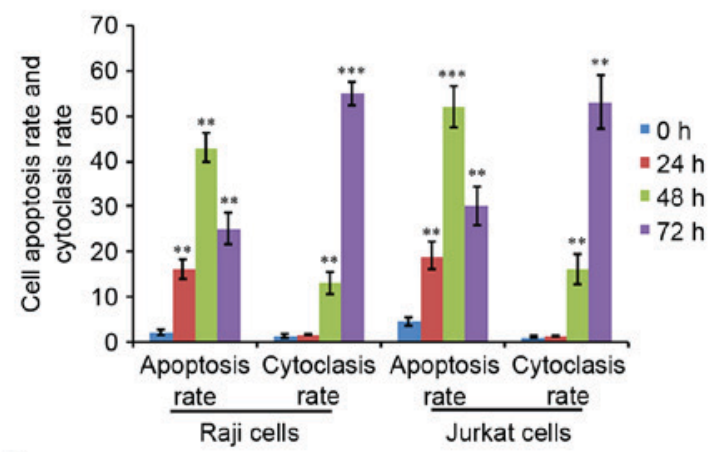

B
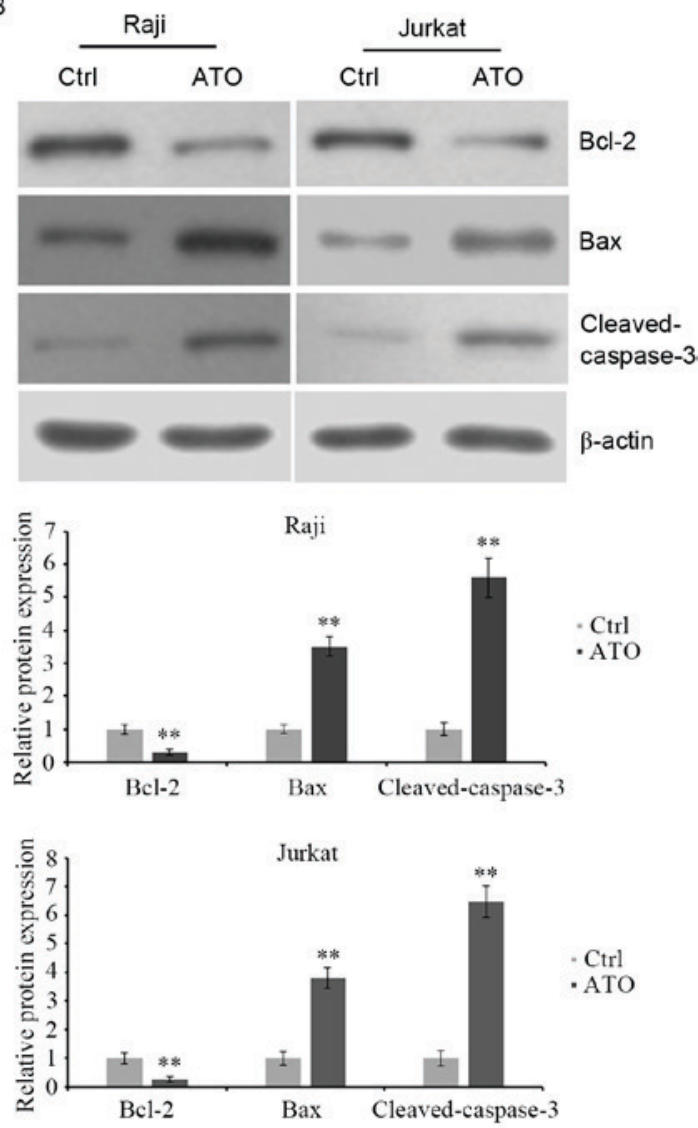

Figure 3. Apoptosis and cytoclasis rate of Raji and Jurkat cells following ATO treatment. (A) Raji and Jurkat cells were treated with 2 and $3.5 \mu \mathrm{M}$ ATO, respectively, for $0,24,48$ and $72 \mathrm{~h}$. The rate of cell apoptosis and cytoclasis were evaluated by flow cytometry, (B) Cells were treated with ATO treatment for $48 \mathrm{~h}$ and the levels of anti-apoptotic protein Bcl-2, pro-apoptotic protein Bax and cleaved caspase- 3 were detected by western blot analysis. $\beta$-actin was detected as internal reference. ${ }^{* *} \mathrm{P}<0.01$ and ${ }^{* * *} \mathrm{P}<0.001$ vs ATO-untreated cells. ATO, arsenic trioxide; Bcl-2, B-cell lymphoma-2; Bax, Bcl-2-associated X; Ctrl, control.

NF- $\kappa B$ was initially identified in B lymphocytes and served a role as a regulator of the $\kappa$-immunoglobulin gene (42). NF- $\kappa B$ is located in the cytoplasm in an inactivated state. The activated NF- $\mathrm{KB}$ is translocated into the nucleus where it binds to response elements (RE) specific sequences of DNA, and then recruits co-activators and RNA polymerase to regulate gene transcription and thus affect translation, resulting in an alteration in cell function $(22,43,44)$. Previous studies have indicated that NF- $\mathrm{KB}$ activation is closely associated with tumorigenesis and drug resistance in tumors $(45,46)$. Beuso-Ramos et al $(47)$ demonstrated that expression of NF- $\mathrm{KB}$ in acute medullocell
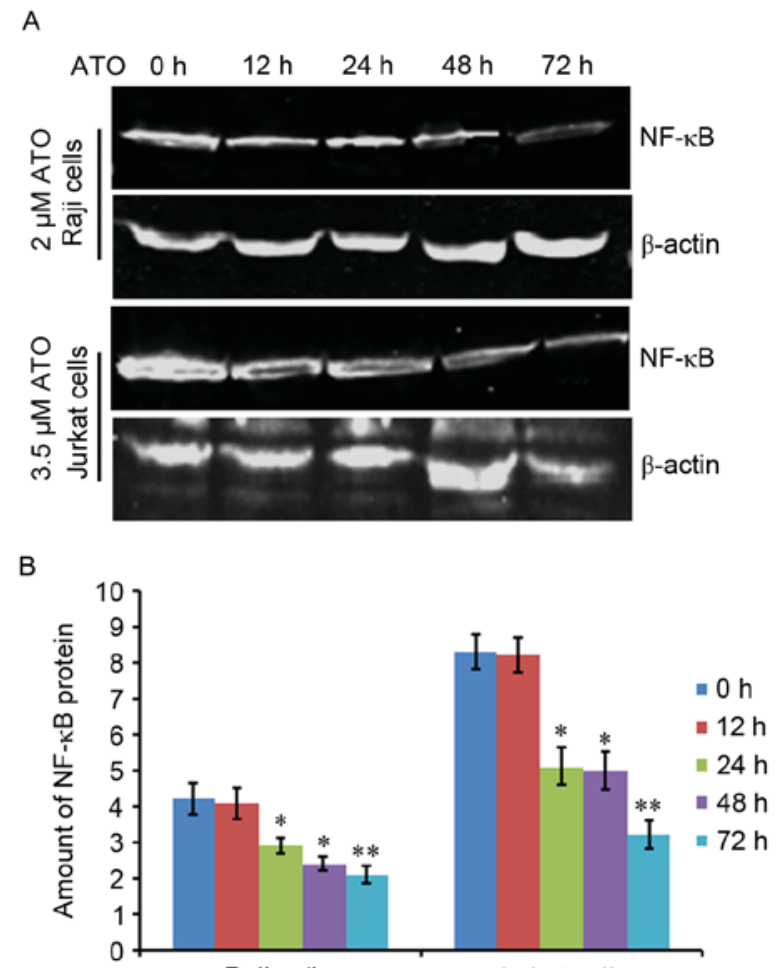

C

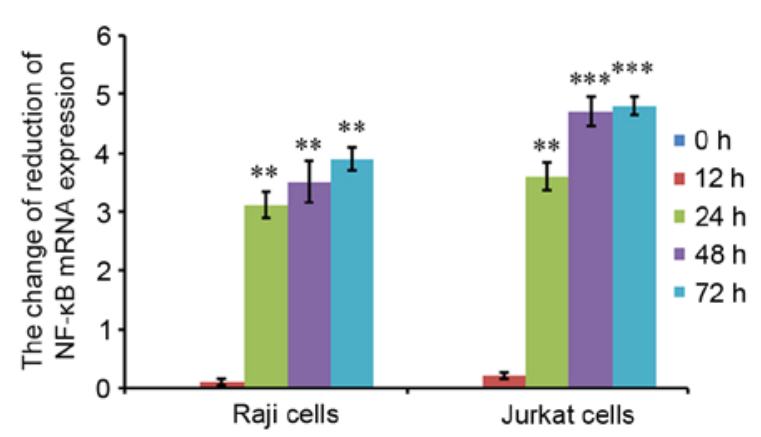

Figure 4. NF-кB protein and mRNA expression levels in Raji and Jurkat cells prior to and following ATO treatment. (A) Raji and Jurkat cells were treated with 2 and $3.5 \mu \mathrm{M}$ ATO, respectively, for $0,12,24,48$ and $72 \mathrm{~h}$. NF-кB protein expression was examined by western blot analysis. $\beta$-actin was used as an internal reference. (B) Protein expression levels were quantified. The bar graph depicts the quantity of NF- $\kappa \mathrm{B}$ protein normalized to $\beta$-actin. (C) The expression levels of NF- $\mathrm{KB}$ mRNA was detected by reverse transcription-quantitative polymerase chain reaction. The differences in NF- $\kappa \mathrm{B}$ mRNA expression in the two cell lines prior to and following ATO treatment were shown. ${ }^{*} \mathrm{P}<0.05,{ }^{* *} \mathrm{P}<0.01$ and ${ }^{* * *} \mathrm{P}<0.001$ vs. ATO-untreated cells. ATO, arsenic trioxide; $\mathrm{NF}-\mathrm{\kappa B}$, nuclear factor- $\mathrm{\kappa} \mathrm{B}$.

leukemia cells was frequently upregulated, and therefore the cells may have escaped from apoptosis via the regulation of certain apoptosis-resistant genes through expression of NF- $\mathrm{KB}$. Hinz et al (48) revealed that ATO inhibited NF- $\mathrm{\kappa B}$ activation followed by its degradation, and consequently induced the apoptosis of leukemia cells. ATO was also reported to induce apoptosis and incapacitate proliferation and invasive properties through possible NF- $\kappa \mathrm{B}$-mediated inhibition of survivin and telomerase activity, and NF- $\mathrm{BB}$-dependent suppression of cathepsin B, matric metalloproteinase (MMP)-2 and MMP-9 in U87-MG glioblastoma cells (49). A further previous study demonstrated that ATO may prevent NF- $\mathrm{KB}$ from nuclear translocation, which thereby led to NF- $\mathrm{kB}$ inactivation, either 


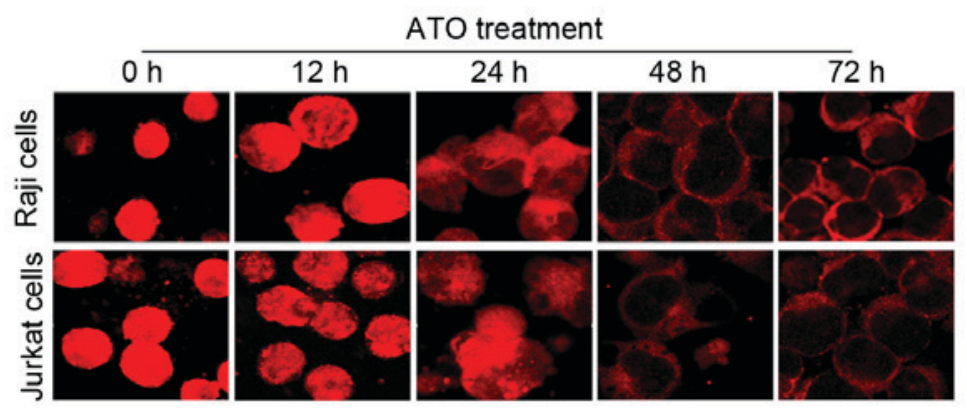

Figure 5. ATO treatment affects expression of NF-кB by immunofluorescence assay. Raji and Jurkat cells were treated with 2 and $3.5 \mu \mathrm{M}$ ATO, respectively,

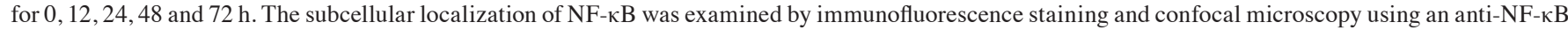

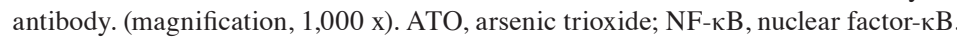

by upregulation and stabilization of expression of $\mathrm{NF}-\kappa \mathrm{B}$ inhibitory factor $\mathrm{I} \kappa \mathrm{B}$, or by suppression of $\mathrm{I} \kappa \mathrm{B}$ kinase, which blocked the degradation of $\mathrm{I} \kappa \mathrm{B}(50)$. Immunofluorescence analysis performed in the present study revealed that $\mathrm{NF}-\kappa \mathrm{B}$ existed in the nucleus and cytoplasm of lymphoma cells prior to ATO treatment, whereas nuclear $N F-\kappa B$ was gradually decreased following ATO treatment, and was possibly inactivated or degraded. Endonuclear NF- $\mathrm{kB}$ was almost completely degraded following ATO treatment for $48 \mathrm{~h}$, whereas the expression of cytoplasmic NF- $\kappa \mathrm{B}$ was observed, which provided evidence of synchronism in $\mathrm{T}$ lymphoma Jurkat and B lymphoma Raji cells. Thus, it was concluded that ATO inhibited the proliferation of lymphoma cells by influencing the intracellular localization of $\mathrm{NF}-\kappa \mathrm{B}$.

The present study revealed that the $N F-\kappa B$ gene and protein were highly expressed in lymphoma cells prior to ATO treatment, with greater expression levels observed in in $\mathrm{T}$ lymphoma cells than in B lymphoma cells, which was in accordance with clinical therapeutic effectiveness and prognosis of $\mathrm{T}$ cell lymphoma compared with $\mathrm{B}$ cell lymphoma identified in a preliminary study (data not shown). Following ATO treatment for $24 \mathrm{~h}, \mathrm{NF}-\kappa \mathrm{B}$ gene and protein expression levels began to change and the rates of cell apoptosis significantly increased in $\mathrm{T}$ and $\mathrm{B}$ lymphoma cells, indicating that ATO inhibited the proliferation of lymphoma cells, possibly by inducing apoptosis. In addition, it was found that in $\mathrm{B}$ cell lymphoma cells, NF- $\kappa \mathrm{B}$ gene and protein expression did not vary greatly between the three ATO treatment time points (24, 48 and $72 \mathrm{~h}$ ), whereas in T cell lymphoma cells, $\mathrm{NF}-\kappa \mathrm{B}$ gene expression did not exhibit a change following ATO treatment for $48 \mathrm{~h}$; NF- $\kappa \mathrm{B}$ protein expression was relatively stable between 24 and $48 \mathrm{~h}$, but dropped markedly after $72 \mathrm{~h}$. These data demonstrated that NF- $\kappa \mathrm{B}$ expression in lymphoma altered following $24 \mathrm{~h}$ ATO treatment, and the subsequent stable NF-кB expression between 24 and $48 \mathrm{~h}$ in the two cell lines may imply that $N F-\kappa B$ is an upstream promoter of ATO induced apoptosis pathway in lymphoma cells, and inhibition of $\mathrm{NF}-\kappa \mathrm{B}$ activity would further regulate downstream signal transduction molecules such as vascular endothelial growth factor (VEGF). Previous studies have reported that $\mathrm{NF}-\kappa \mathrm{B}$ targets the VEGF gene, which has a specific binding site for $\mathrm{NF}-\kappa \mathrm{B}$ on its promoter $(51,52)$. When $\mathrm{NF}-\kappa \mathrm{B}$ is activated by external stimulation, it translocates into the nucleus; the activated $\kappa \mathrm{B}$ sequence then binds to the VEGF promoter to promote the transcription to upregulate
VEGF expression and thus induces tumor neovascularization $(51,52)$. Whether downregulated NF- $\kappa \mathrm{B}$ influences VEGF directly or through a series of signal transduction pathways following ATO treatment remains unclear, with further investigation required.

The present study revealed that $\mathrm{NF}-\kappa \mathrm{B}$ gene and protein expression in $\mathrm{T}$ cell lymphoma was further downregulated, after being stable for a certain time period following drug treatment; however, the drug concentration required in $\mathrm{T}$ cell lymphoma was greatly increased compared with B cell lymphoma, indicating that the clinical treatment of T cell lymphoma with ATO may require higher doses and a longer administration time to achieve drug efficacy in $\mathrm{T}$ cell lymphoma, compared with B cell lymphoma. However, further clinical research is required to verify this hypothesis.

\section{Acknowledgements}

Not applicable.

\section{Funding}

No funding was received.

\section{Availability of data and materials}

The datasets used and/or analyzed during the current study are available from the corresponding author on reasonable request.

\section{Authors' contributions}

$\mathrm{LZ}$ and FC were major contributors in the conception and design of the research, and revised the manuscript for important intellectual content. Acquisition of data was performed by FX. LZ was the major contributor in the analysis and interpretation of data and statistical analysis. Drafting the manuscript was performed by FC.

\section{Ethics approval and consent to participate}

Not applicable.

\section{Patient consent for publication}

Not applicable. 


\section{Competing interests}

The authors declare that they have no competing interests.

\section{References}

1. Taylor,Elizabeth J: Dorland's Illustrated medical dictionary. (29th ed.). Philadelphia, Saunders, pp1038, 2000. ISBN 0721662544.

2. General Information About Adult Hodgkin Lymphoma. National Cancer Institute 2014-04-23. Retrieved 20 June, 2014

3. General Information About Adult Non-Hodgkin Lymphoma National Cancer Institute. 2014-04-25. Retrieved 20 June, 2014.

4. Tsai SC, Lu CC, Lee CY, Lin YC, Chung JG, Kuo SC, Amagaya S, Chen FN, Chen MY, Chan SF and Yang JS: AKT serine/threonine protein kinase modulates bufalin-triggered intrinsic pathway of apoptosis in CAL 27 human oral cancer cells. Int J Oncol 41: 1683-1692, 2012

5. Umit UM, Berna T, Handan K, Ipek E, Berrak Y, Can E and Bahadir GM: Role of melatonin and luzindole in rat mammary cancer. J Invest Surg 25: 345-353, 2012.

6. Valk PJ, Verhaak RG, Beijen MA, Erpelinck CA, Barjesteh van Waalwijk van Doorn-Khosrovani S, Boer JM, Beverloo HB Moorhouse MJ, van der Spek PJ, Löwenberg B and Delwel R.: Prognostically useful gene-expression profiles in acute myeloid leukemia. N Engl J Med 350: 1617-1628, 2004.

7. Cotter TG: Apoptosis and cancer: the genesis of a research field. Nat Rev Cancer 9: 501-507, 2009.

8. Reed JC: Dysregulation of apoptosis in cancer. J Clin Oncol 17: 2941-2953, 1999

9. Li Y, Xing D, Chen Q and Chen WR: Enhancement of chemotherapeutic agent-induced apoptosis by inhibition of NF-kappaB using ursolic acid. Int J Cancer 127: 462-473, 2010.

10. Shi M, Lu XJ, Zhang J, Diao H, Li G, Xu L, Wang T, Wei J, Meng W, Ma JL, et al: Oridonin, a novel lysine acetyltransferases inhibitor, inhibits proliferation and induces apoptosis in gastric cancer cells through p53- and caspase-3-mediated mechanisms Oncotarget 7: 22623-22631, 2016.

11. Yang P, Zhao J, Hou L, Yang L, Wu K and Zhang L: Vitamin E succinate induces apoptosis via the PI3K/AKT signaling pathways in EC109 esophageal cancer cells. Mol Med Rep 14: $1531-1537,2016$.

12. Grund SC, Hanusch K and Wolf HU: Arsenic and arsenic compounds, Ullmann's encyclopedia of industrial chemistry. Weinheim, Wiley-VCH, 2005.

13. Gielen M and Tiekink ER: Metallotherapeutic drugs and metal-based diagnostic agents. Wiley, pp298, 2005. ISBN 0-470-86403-6.

14. Zhou LY, Chen FY, Shen LJ, Wan HX and Zhong JH: Arsenic trioxide induces apoptosis in the THP1 cell line by downregulating EVI-1. Exp Ther Med 8: 85-90, 2014.

15. Wang $S$, Zhou $M$, Ouyang J, Geng $Z$ and Wang $Z$ : Tetraarsenictetrasulfide and arsenic trioxide exert synergistic effects on induction of apoptosis and differentiation in acute promyelocytic leukemia cells. PLoS One 10: e0130343, 2015.

16. Ghaffari SH, Yousefi M, Dizaji MZ, Momeny M, Bashash D, Zekri A, Alimoghaddam K and Ghavamzadeh A: Arsenic trioxide induces apoptosis and incapacitates proliferation and invasive properties of U87MG Glioblastoma cells through a Possible NF- $\kappa \mathrm{B}$-mediated mechanism. Asian Pac J Cancer Prev 17: 1553-1564, 2016.

17. Sun XP, Zhang X, He C, Qiao H, Jiang X, Jiang H and Sun X ABT-737 synergizes with arsenic trioxide to induce apoptosis of gastric carcinoma cells in vitro and in vivo. J Int Med Res 40: 1251-1264, 2012.

18. Wang Y, Wang L, Yin C, An B, Hao Y, Wei T, Li L and Song G: Arsenic trioxide inhibits breast cancer cell growth via microRNA-328/hERG pathway in MCF-7 cells. Mol Med Rep 12: 1233-1238, 2015 .

19. Walker AM, Stevens JJ, Ndebele K and Tchounwou PB: Evaluation of arsenic trioxide potential for lung cancer treatment: Assessment of apoptotic mechanisms and oxidative damage. J Cancer Sci Ther 8: 1-9, 2016.

20. Hu HT, Yao QJ, Meng YL, Li HL, Zhang H, Luo JP, Guo CY and Geng X: Arsenic trioxide intravenous infusion combined with transcatheter arterial chemoembolization for the treatment of hepatocellular carcinoma with pulmonary metastasis: Long-term outcome analysis. J Gastroenterol Hepatol 32: 295-300, 2016.
21. Ally MS, Ransohoff K, Sarin K, Atwood SX, Rezaee M, Bailey-Healy I, Kim J, Beachy PA, Chang AL, Oro A, et al: Effects of combined treatment with arsenic trioxide and Itraconazole in patients with refractory metastatic basal cell carcinoma. JAMA Dermatol 152: 452-456, 2016.

22. Gilmore TD: Introduction to NF-kappaB: Players, pathways, perspectives. Oncogene 25: 6680-6684, 2006.

23. Vlahopoulos SA, Cen O, Hengen N, Agan J, Moschovi M, Critselis E, Adamaki M, Bacopoulou F, Copland JA, Boldogh I, et al: Dynamic aberrant NF- $\mathrm{B}$ spurs tumorigenesis: A new model encompassing the microenvironment. Cytokine Growth Factor Rev 26: 389-403, 2015.

24. Monaco C, Andreakos E, Kiriakidis S, Mauri C, Bicknell C, Foxwell B, Cheshire N, Paleolog E and Feldmann M: Canonical pathway of nuclear factor kappa B activation selectively regulates proinflammatory and prothrombotic responses in human atherosclerosis. Proc Natl Acad Sci USA 101: 5634-5639, 2004.

25. Vidal PM, Lemmens E, Dooley D and Hendrix S: The role of 'anti-inflammatory' cytokines in axon regeneration. Cytokine Growth Factor Rev 24: 1-12, 2013.

26. Bonavita E, Galdiero MR, Jaillon S and Mantovani A: Phagocytes as corrupted policemen in cancer-related inflammation. Adv Cancer Res 128: 141-171, 2015.

27. Weniger MA and Küppers R: NF- $\kappa B$ deregulation in Hodgkin lymphoma. Semin Cancer Biol 39: 32-39, 2016.

28. Pasqualucci L and Zhang B: Genetic drivers of NF- $\kappa$ B deregulation in diffuse large B-cell lymphoma. Semin Cancer Biol 39: 26-31, 2016

29. Liu X, Lv Y, Xie Y, Hong Q, Cai G, Zhang S, Liu W and Chen X: Change of MAX interactor 1 expression in an anti-Thyl nephritis model and its effect on mesangial cell proliferation. Cell Physial Biochem 27: 391-400, 2011

30. Ohkubo T and Ozawa M: p120(ctn) binds to the membrane-proximal region of the E-cadherin cytoplasmic domain and is involved in modulation of adhesion activity. J Biol Chem 274: 21409-21415, 1999.

31. Chen GQ, Zhu J, Shi XG, Ni JH, Zhong HJ, Si GY, Jin XL, Tang W, Li XS, Xong SM, et al: In vitro studies on cellular and molecular mechanisms of arsenic trioxide (As2O3) in the treatment of acute promyelocytic leukemia: As2O3 induces NB4 cell apoptosis with downregulation of $\mathrm{Bcl}-2$ expression and modulation of PML-RAR alpha/PML proteins. Blood 88: 1052-1061, 1996.

32. Bazarbachi A, El-Sabban ME, Nasr R, Quignon F, Awaraji C, Kersual J, Dianoux L, Zermati Y, Haidar JH, Hermine O and de Thé $\mathrm{H}$ : Arsenic trioxide and interferon-alpha synergize to induce cell cycle arrest and apoptosis in human T-cell lymphotropic virus type I-transformed cells. Blood 93: 278-283, 1999.

33. Livak KJ and Schmittgen TD: Analysis of relative gene expression data using real-time quantitative PCR and the 2(-Delta Delta C(T)) method. Methods 25: 402-408, 2001.

34. Zhu XH, Shen YL, Jing YK, Cai X, Jia PM, Huang Y, Tang W, Shi GY, Sun YP, Dai J, et al: Apoptosis and growth inhibition in malignant lymphocytes after treatment with arsenic trioxide at clinically achievable concentrations. J Natl Cancer Inst 91: 772-778, 1999 .

35. Zhou L, Jing Y, Styblo M, Chen Z and Waxman S: Glutathione-s-trandferase pi inhibits As2O3-induced apoptosis in lymphoma cells: Involvement of hydrogen peroxide catabolism. Blood 105: 1198-1203, 2005.

36. Soignet SL, Maslak P, Wang ZG, Jhanwar S, Calleja E, Dardashti LJ, Corso D, DeBlasio A, Gabrilove J, Scheinberg DA, et al: Complete remission after treatment of acute promyelocytic leukemia with arsenic trioxide. N Engl J Med 339: 1341-1348, 1998.

37. Zamzami N, Hirsch T, Dallaporta B, Petit PX and Kroemer G: Mitochondria implication in accidental and programmed cell death: Apoptosis and necrosis. J Bioenerg Biomembr 29: 185-193, 1997.

38. Daj J, Weinberg RS, Waxman S and Jing Y: Malignant cells can be sensitized to undergo growth inhibition and apoptosis by arsenic trioxide through modulation of the glutathione redox system. Blood 93: 268-277, 1999.

39. Shen L, Chen TX, Wang YP, Lin Z, Zhao HJ, Zu YZ, Wu G and Ying DM: As2O3 induces apoptosis of the human B lymphoma cell line MBC-1. J Biol Regul Homeost Agents 14: 116-119, 2000.

40. Korper S, Nolte F, Thiel E, Schrezenmeier H and Rojewski MT: The role of mitochondrial targeting in arsenic trioxide induced apoptosis in myeloid cell lines. Br J Haematol 124: 186-189, 2004. 
41. Ghaffari SH, Momeny M, Bashash D, Mirzaei R, Ghavamzadeh A and Alimoghaddam K: Cytotoxic effect of arsenic trioxide on acute promyelocytic leukemia cells through suppression of $\mathrm{NFk} \beta$-dependent induction of hTERT due to down-regulation of Pin1 transcription. Hematology 17: 198-206, 2012.

42. Kaileh $M$ and Sen R: NF- $\kappa$ B function in B lymphocytes. Immunol Rev 246: 254-271, 2012.

43. Brasier AR: The NF-kappaB regulatory network. Cardiovasc Toxicol 6: 111-130, 2006.

44. Perkins ND: Integrating cell-signalling pathways with NF-kappaB and IKK function. Nat Rev Mol Cell Biol 8: 49-62, 2007.

45. Sun W, Guo L, Shao G, Liu X, Guan Y, Su L and Zhao S: Suppression of LASP-1 attenuates the carcinogenesis of prostatic cancer cell lines: Key role of the NF- $\mathrm{BB}$ pathway. Oncol Rep 37: 341-347, 2017.

46. Bentires-Alj M, Barbu V, Fillet M, Chariot A, Relic B, Jacobs N, Gielen J, Merville MP and Bours V: NF-kappaB transcription factor induces drug resistance through MDR1 expression incancer cells. Oncogene 22: 90-97, 2003.

47. Bueso-Ramos CE, Rocha FC, Shishodia S, Medeiros LJ, Kantarjian HM, Vadhan-Raj S, Estrov Z, Smith TL, Nguyen MH and Aggarwal BB: Expression of constitutively active nuclear-kappaB RelA transcription factor in blasts of acute myeloid leukemia. Hum Pathol 35: 246-253, 2004.

48. Hinz M, Lemke P, Anagnostopoulos I, Hacker C, Krappmann D, Mathas S, Dörken B, Zenke M, Stein H and Scheidereit C: Nuclear factor kappaB-dependent gene expression profiling of Hodgkin's disease tumor cells, pathogenetic significance, and link to constitutive signal transducer and activator of transcription 5a activity. J Exp Med 196: 605-617, 2002.
49. Ghaffari SH, Yousefi M,Dizaji MZ, Momeny M,Bashash D,Zekri A, Alimoghaddam K and Ghavamzadeh A: Arsenic trioxide induces apoptosis and incapacitates proliferation and invasive properties of U87MG Glioblastoma cells through a possible NF-kB-mediated mechanism. Asian Pac J Cancer Prev 17: 1553-1564, 2016.

50. Lee YJ, Hwang SM, Yoon JJ, Lee SM, Kyung EH, Kim JS, Kang DG and Lee HS: Inhibitory effect of Thuja orientalis on TNF- $\alpha$-induced vascular inflammation. Phytother Res 24: $1489-1495,2010$

51. Godzich M, Hodnett M, Frank JA, Su G, Pespeni M, Angel A, Howard MB, Matthay MA and Pittet JF: Activation of the stress protein response prevents the development of pulmonary edema by inhibiting VEGF cell signaling in a model of lung ischemia-reperfusion injury in rats. Blood 2: 1519-1521, 2006.

52. Loennechen T, Mathisen B, Hansen J, Lindstad RI, El-Gewely SA, Andersen K, Maelandsmo GM and Winberg JO: Colchicine induces membrane-associated activation of matrix metalloproteinase-2 in osteosarcoma cells in an s100A4-independent manner. Biochem Pharmacol 66: 2341-2353, 2003.

This work is licensed under a Creative Commons Attribution-NonCommercial-NoDerivatives 4.0 International (CC BY-NC-ND 4.0) License. 